$\mathbb{T}$ periodica polytechnica

Architecture

$42 / 1(2011) 23331$

doi: 10.3311/pp.ar.2011-1.03

web: http://www.pp.bme.hu/ar

(c) Periodica Polytechnica 2011

RESEARCH ARTICLE

\section{World Exhibitions as laboratories for structural innovation}

Bálint Kádár

Received 2011-01-17

\begin{abstract}
Architecture since the industrial revolution has been determined by technological innovation more than ever before. To realise buildings with large-span structures or transparent coverings, high cost structures had to be developed and built. World Exhibitions - or Expos - are events originally held by nations to show their industrial, economic and cultural power. Due to the representative nature of these fairs, financial resources and innovative approaches are granted for structural and architectural experiments. This paper presents an overview of the main structural innovations of the past two centuries, selecting those first presented at Expos. The numerous innovations from prefabrication, great steel trusses, and transparent coverings to geodesic domes, membrane structures and steel coatings could only spread in different architectural situations, if these were successfully tested in the large-scale laboratories of World Exhibitions. The process is the same today, but the innovation is about green technologies and computer aided production, rather than large span structures.
\end{abstract}

\section{Keywords}

World Exhibitions · expo · large-span structures $\cdot$ structural innovation

\section{Bálint Kádár}

Department of History of Architecture and of Monuments, BME, H-1111, Budapest, Múegyetem rkp. 3, Hungary

e-mail: balint.kadar@gmail.com

\section{Introduction}

World Exhibitions are the great showcases where nations connected to global trade routes present the products of their industries, their cultural achievements and their vision for the future.

The single exhibitions held since the middle of the $19^{\text {th }}$ century are all well documented, and numerous publications analyse their effects on culture, society and design. Even though the great architectural achievements tied to these world fairs are well known and published [1], there is no comprehensive work on how new architectural ideas and structures were experimented with in the succession of world exhibitions. This paper tries to define which principal structural developments were first introduced to architecture in these expos. The hypothesis is simple: World fairs were always among the principal laboratories for structural innovation in architecture. These events were born to be the first showcases of not only industrial and cultural products, but also of great architectural achievements. As singular nations held these expos, the will to compete in more and more innovative and spectacular structures was always strong, and funds to construct experimental building technologies were more accessible than in any other profit oriented construction situation.

World Exhibitions started with the Industrial Revolution, as the world became more connected by railroads, the telegraph and steamships, so trade also had to grow globally; the big fairs were excellent occasions to make new connections.

The origin of all world fairs was the Exhibition of French Industrial Products, held since 1798. The popular exhibition was held on eleven occasions, and at the last one, held in 1849 in Champs Elysées, Paris, recorded 4494 exhibitors. London, after hosting minor national exhibitions, held the first true World Fair in 1851. Held in a completely prefabricated glass and steel structure - the Crystal Palace, this event opened a new era for large span architectural structures.

\section{Steel trusses and glass coverings}

The Great Exhibition of the Works of Industry of all Nations was to be held in one temporary building near London's city centre, in Hyde Park. Following an unsuccessful competition, 
only a limited time was left to build something bigger and more spectacular than all the temporary pavilions of the French fairs. The engineer who could build such a structure was Joseph Paxton, originally a gardener, who had some experience in glass house building. His concept of a great glass house convinced the Royal Commission after he developed full construction plans in two weeks [8, pp. 40-80]. The Crystal Palace was the first public building made of an entirely glazed cast iron and timber structure (Fig. 1). It had $92,000 \mathrm{~m}^{2}$ of exhibition space, the length was $564 \mathrm{~m}$ and the height $33 \mathrm{~m}$. Only a few months from September 1950 to January 1951 were needed to construct it. This was made possible by the prefabrication of both steel and glass elements, brought on site by rail and constructed without any "wet" technology needed. The modular system of the construction was based on the maximum size of glass sheets $(1.25$ meters) that could be produced at a reasonable cost. Crystal Palace therefore marked the beginning of building prefabrication as well as the era of steel and glass architecture - already being used in railway stations, galleries and industrial buildings. The palace was relocated after the closing of the exhibition to Penge Place in London. The enlarged building served as a multifunctional leisure facility that hosted concerts, exhibitions and various forms of entertainment. Until it burnt down in 1936, it was one of the biggest interior spaces open for public activities. The building allowed people to enjoy their free time in large, naturally lit spaces with a feeling of being in an open space but protected from environmental effect 1 This building expressed the new possibilities of an industrial age, and did not only contribute to the spread of iron and glass in architecture in its time, but also it anticipated the new modernist architecture of the $20^{\text {th }}$ century [6, p. 252].

Crystal Palace was copied in New York (NY Crystal Palace, Exhibition of the Industry of All Nations, 1853) and Munich (Glaspalast, Erste Allgemeine Deutsche Industrieausstellung, 1854) with the same structural system and same overall appearance (NY palace had a Greek-cross plan with a 30 meter high dome in the centre). However it was not long before new solutions were experimented with to expand the possibilities of the new building materials.

France aimed to create exhibitions that could overpass the glory of 1851. The Exposition Universelle of 1889 was held in Paris. The majesty of the expo was represented by the entrance arch, namely the Eiffel Tower. The steel tower with its record height was only one of the structures to break records. An equally important building designed by architect Ferdinand Dutert and engineer Victor Contamin intended to surpass the size of Crystal Palace. The Galerie des Machines [6, pp. 455459], had a 111 meters wide main hall, spanned using threehinged arch trusses made of iron (not steel, as planned before). All glazed, it has had the largest floor area of all time with di-

\footnotetext{
${ }^{1}$ In sunny summer days blinds needed to be installed on the exterior of the glass panels to reduce inner heat and light.
}

mensions of the main hall of $115 \mathrm{~m} \mathrm{x} 420 \mathrm{~m}$ and $43.5 \mathrm{~m}$ in height (Fig.2).

\section{Concrete structures}

For the 1900 Universal Exhibition also held in Paris, a new building with a glazed roof was built. The Grand Palais had only its roof structure in steel and glazed, and it did not reach the sizes of the Machine Hall, still in use then. Steel trusses had reached their limits, but space structures or grid shell structures of steel and reinforced concrete were to come in the $20^{\text {th }}$ century, and exposition halls were still the best occasions for experimentation.

The most important milestone in modernist architecture presented at a World Fair was the German Pavilion for the 1929 International Exposition held in Barcelona. Mies van der Rohe designed this small pavilion to represent the openness and modernity of the new Weimar Germany, but the Barcelona Pavilion became much more than that, a representative of the modernist movement in architecture. Even though this small building was capable of having a big influence, the biggest quest was still to build large exhibition halls.

Undoubtedly, the most influential structural achievements in the early $20^{\text {th }}$ century were those in reinforced concrete. Concrete as a building material was first used at the Paris Exhibition of 1867 , for the floors and basement areas of the main building [6. p. 325]. Concrete structures were later developed to span large spaces with various beams and trusses, with prestressed concrete and also with the development of different shell structures. The sports halls and cathedrals of Pier Luigi Nervi [2, pp. 176-180] are among the greatest concrete structures in architecture, among them is the Agnelli Exhibition Hall (1949-50) of Torino. The vaulted roof structure was made with partial prefabrication using Nervi's precast "ferrocemento" technique, combining thin (less than $4 \mathrm{~cm}$ ) prefabricated cement shells and on-site concrete works. The roof structure spanned 73 meters the covered space was 94 meters long.

For the 1961 exposition, celebrating the centenary of the Italian state, an even bigger hall was needed. Nervi won the competition to build another hall in Turin, the Palazzo del Lavoro (with Gio Ponti, 1961). The built pavilion was 160x160 meters in size, with 16 concrete pillars supporting "mushroom" structures of $38 \times 38$ meters made out of steel trusses.

\section{Space frames}

Concrete structures were feasible for building great halls, but over a certain size, inner spaces are no longer perceptible, while the relatively dense structural elements of the roof could not be comprehended as an open space -something that Paxton's Crystal palace already knew in 1851 . To revive that feeling without inner supporting pillars, steel trusses had evolved into threedimensional frames. Space frames [4] or space grid structures are constructed from interlocking struts in a geometric pattern, usually with multidirectional triangular frames as constructive 


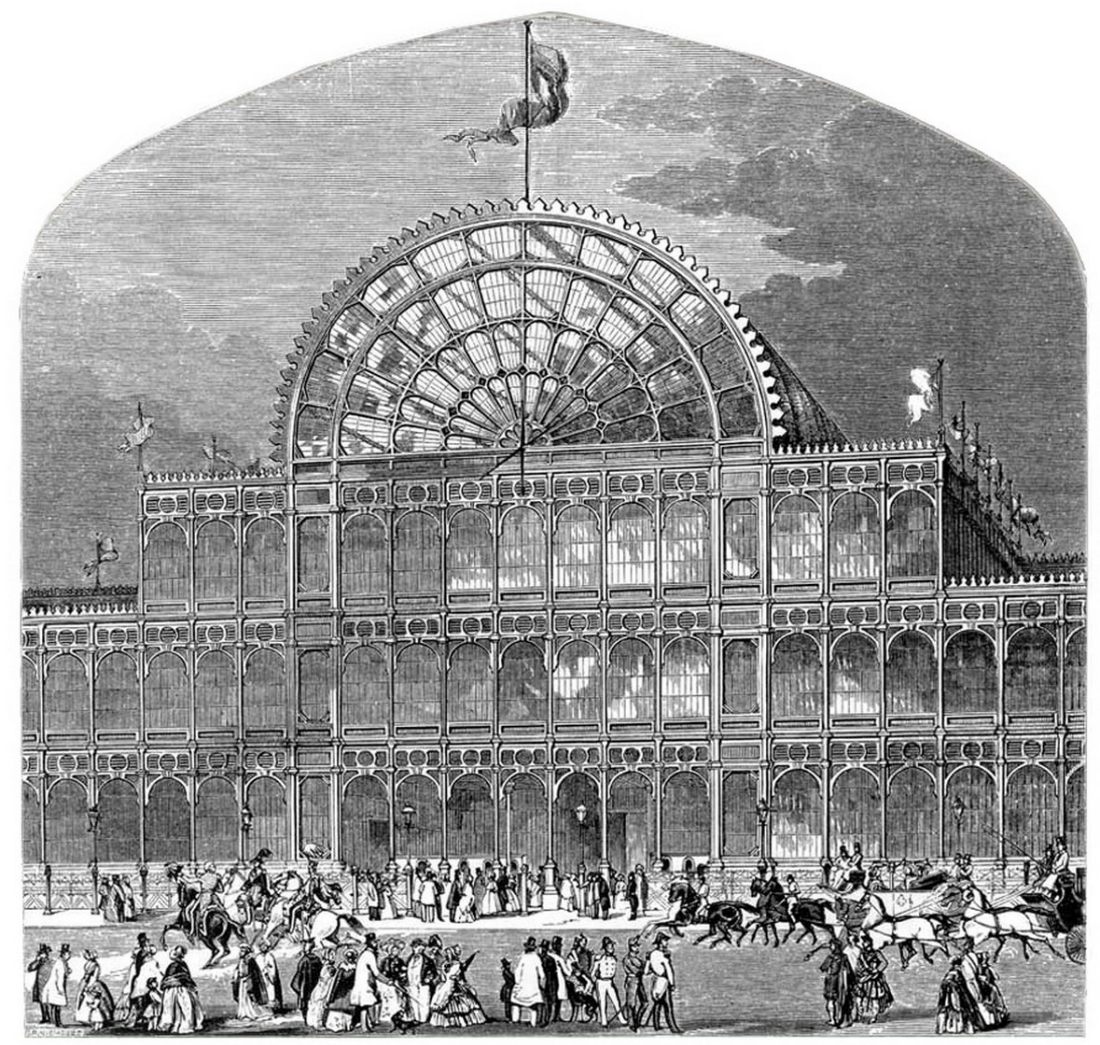

Fig. 1. London, Hyde Park, the front entrance of the Crystal Palace, 1851. (source: contemporary engraving)

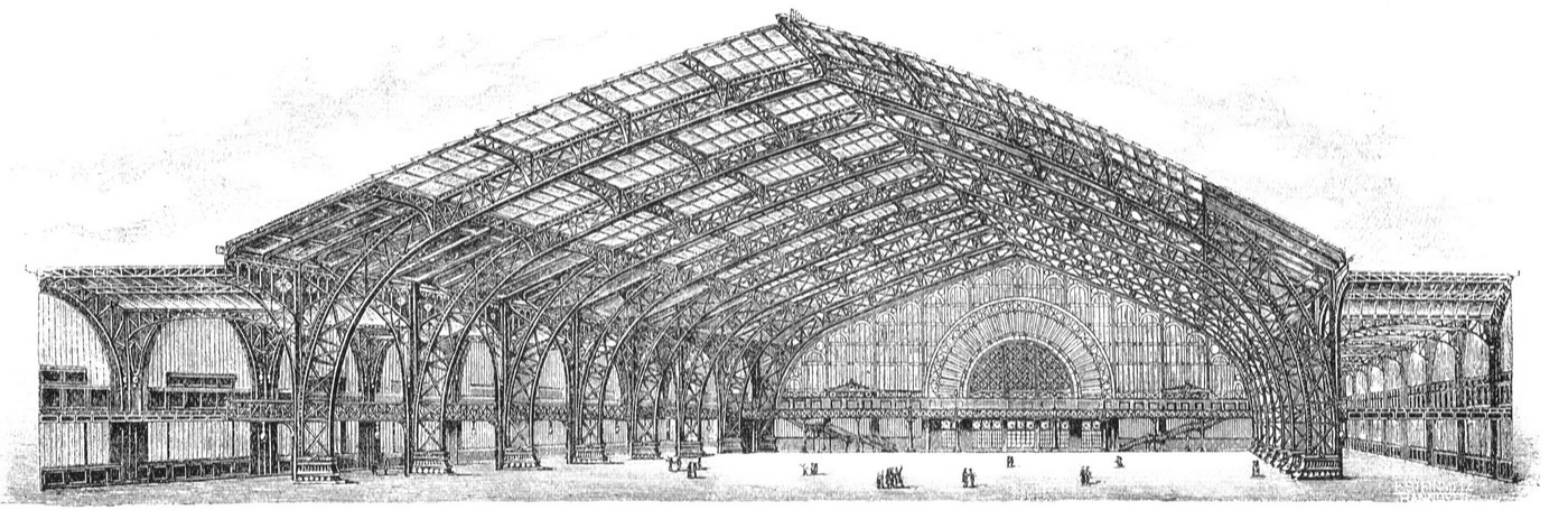

Fig. 2. Paris, Machine hall, interior view, 1889. (source: Handbuch der Ar-

stadt 1893 )

chitektur, Gebäude für Erzienung und Kunst; Verlag Arnold Bergsträsser; Darm-

elements. Alexander Graham Bell first invented these around 1900 for aeronautical engineering. He constructed an observation tower nearly $25 \mathrm{~m}$ high at Beinn Bhreagh. Space frames were first used in architecture in 1943, when Dr Ing. Max Mengeringhausen developed the MERO system.

The post-war period did not see any significant construction activity with the new steel structures. After the Second World War, no World's Fair was held until the 1958 Expo at Brussels. The symbol of the Expo was the Atomium (André Waterkeyn), designed after the structure of an iron crystal. The monument has an innovative aluminium skin, and its shape also resembles the joints of the space frame, the planar roof structure that became popular in the 1960's and 70's.

The biggest space frame structures were built for the world

\section{Geodesic domes}

The space grid structure could not only be planar, but curved to a spherical shape. Buckminster Fuller constructed his first geodesic dome in 1949 [5] pp. 354-391], with tubular steel

expositions of 1967 and 1970. For the Expo'67 in Montreal "Man the producer" pavilion (by Affleck, Desbarets, Dimakopoulos, Lebensold and Sise), or the Netherlands Pavilion were both giant space frame structures [14]. The greatest space to span with such a construction was a giant roof for the Festival Plaza with a double layer grid space frame for the 1970 Osaka expo, designed by Kenzo Tange with Yoshikatsu Tsuboi Institute + Kawaguchi \& Engineers. It measured $291 \mathrm{~m} \times 108 \mathrm{~m}$, spanning $75.6 \mathrm{~m} \times 108 \mathrm{~m}$ between pillars, and had a transparent membrane covering of thin polyester film [12] (Fig. 3]). 


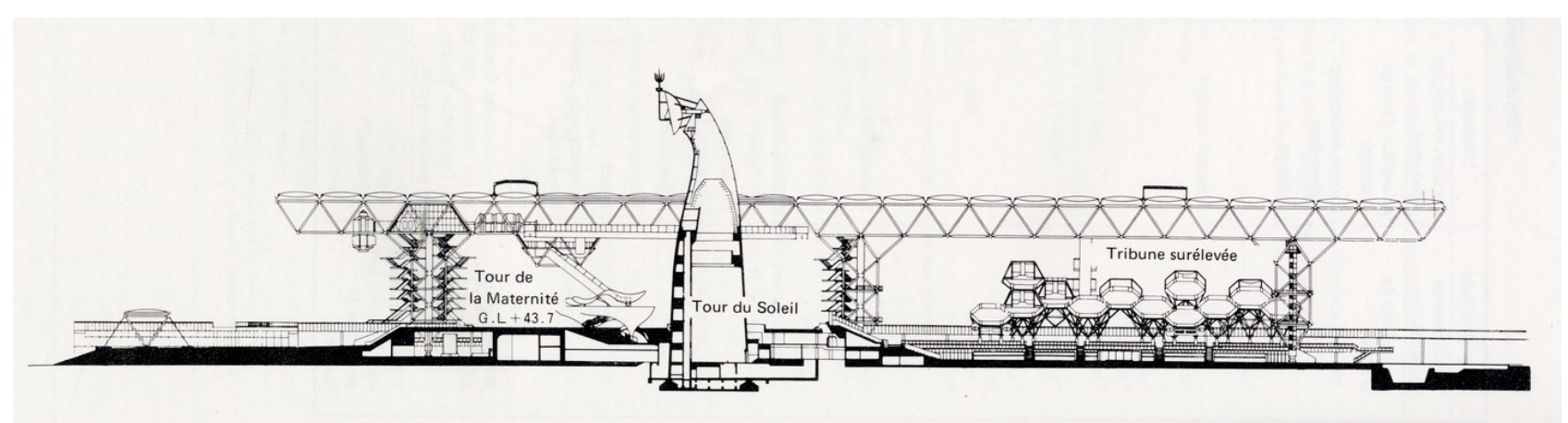

Fig. 3. Osaka, Festivity Hall, section, 1970. (source: ACEUJ, Exposition unvierselle du Japon, Osaka, 1970, rapport officielle, Osaka, 1972)

beams forming an omnitriangulated space frame. The geodesic dome was actually invented in 1922 by Walther Bauersfeld, a German engineer, who created the planetarium in Jena with this structure. Geodesic domes are extremely strong, so large spaces could be created with the minimum quantity of steel and in a relatively short time.

Buckminster Fuller developed the Octet Truss system to build his geodesic domes from 1950.

He constructed large domes at the 1964 World Fair of New York city and the 1967 Montreal Expo (USA pavilion on Fig.4). At the 1970 Osaka exposition, the success of Fuller inspired the French and the German pavilions (architect Fritz Bornemann) which were geodesic domes themselves, and the Sumitomo Tale pavilion (Fig. 5), a structural wonder of nine circular plates covered by half-domes, all suspended on steel pillars at a height of 20-30 meters [18].

Buckminster built one more important geodesic dome in 1982, the Spaceship Earth exhibition space at Disney's Epcot Centre, but industrial and research buildings were also constructed with his technology. Geodesic domes are ideal structures to make highly resistant light-weight enclosed spaces protected from the environment, like the Amundsen-Scott South Pole Station (1975-2003), or the Eden project in the UK (steel space-frame dome, Nicholas Grimshaw with Anthony Hunt and Associates, 2000). The use of these structures never became common, but the idea of the protective dome made engineers dream on a big scale: Buckminster Fuller envisioned large geodesic domes over cities like New York in the 60's, while Frei Otto was working with Kenzo Tange on projects to make new cities in climatic shells (City in the Antarctica, 1971).

\section{Grid shell structures}

Most of the advantages of the geodesic dome are present in grid shell structures, which can be built in various forms that are flatter than domes. In idle conditions only plane stress occurs in the thin shell structure, both tension and compression.

Russian engineer Vladimir Shukhov ${ }^{2}$ first constructed a steel membrane roof in 1896 for the All-Russia Industrial and Art Exhibition in Nizhny Novgorod [7]. The Rotunda building had a

\footnotetext{
${ }^{2}$ Information from http://www. shukhov.org/shukhov.html viewed on 2010.11 .04
}

lattice hanging covering (tensile gridshell, 68 meters in diameter) and the world's first membrane roof in the middle, with a diameter of 25 meters (Fig. 6). Near there, in Vyksa he made a double curved grid shell structure for a factory building in 1887. Shukhov was a pioneer in grid shells, hyperboloid structures (towers) and tent structures. He inspired many engineers of the second half of the $20^{\text {th }}$ century, but only in the $21^{\text {st }}$ century has his innovation begun to be used widely.

The next engineer to use grid shells to cover large spaces was Frei Ottd ${ }^{3}$ He designed a timber grid shell in 1962, and in 1971, the Multihalle Manheim was built for the Federal Garden Festival, spanning 80 meters. Frei Otto continued experimenting with grid shells; in 2000, his Japanese pavilion for the Hannover Expo was designed entirely of paper tubes, spanning 35 meters at the widest point of the 72 meter long pavilion. German authorities permitted its construction only by reinforcing it with timber elements, but the outside membrane and most of the structure was built of paper.

Grid shell structures in steel or composite materials supporting intelligent glass panels were first developed in the 1990's (Aquatoll aqua park, Neckarsulm, Germany, Schlaich, Bergermann und Partner, 1988-1990), making it the canopy technology of the XXI century. Similar membrane-like grid shell structures are widely used today in big urban projects. Many of these are also designed by the office of Jörg Schlaich ${ }^{4}$, a German structural engineer pioneer in grid shell structures among other structural innovations. He was responsible as structural engineer for the 1972 München Olympic Stadion, today his firm designs the biggest glazed canopies in Europe. The firm designed with architect Massimiliano Fuksas the giant canopy covering the main pedestrian axis of the Fiera di Milano, finished in 2005. Slightly curved big surfaces and extremely distorted surfaces can both be observed at Europe's biggest fair site on this undulating roof of $200,000 \mathrm{~m}^{2}$.

\section{Tensile structures and pneumatic structures}

Frei Otto's experimentation with tensile structures and membrane coverings lead to the great tensile roof structure with

\footnotetext{
${ }^{3}$ Information from http: //www . freiotto. com viewed on 2010.11.04.

4 Information on the firm's website, http://www.sbp.de/ viewed on 2010.11.04.
} 


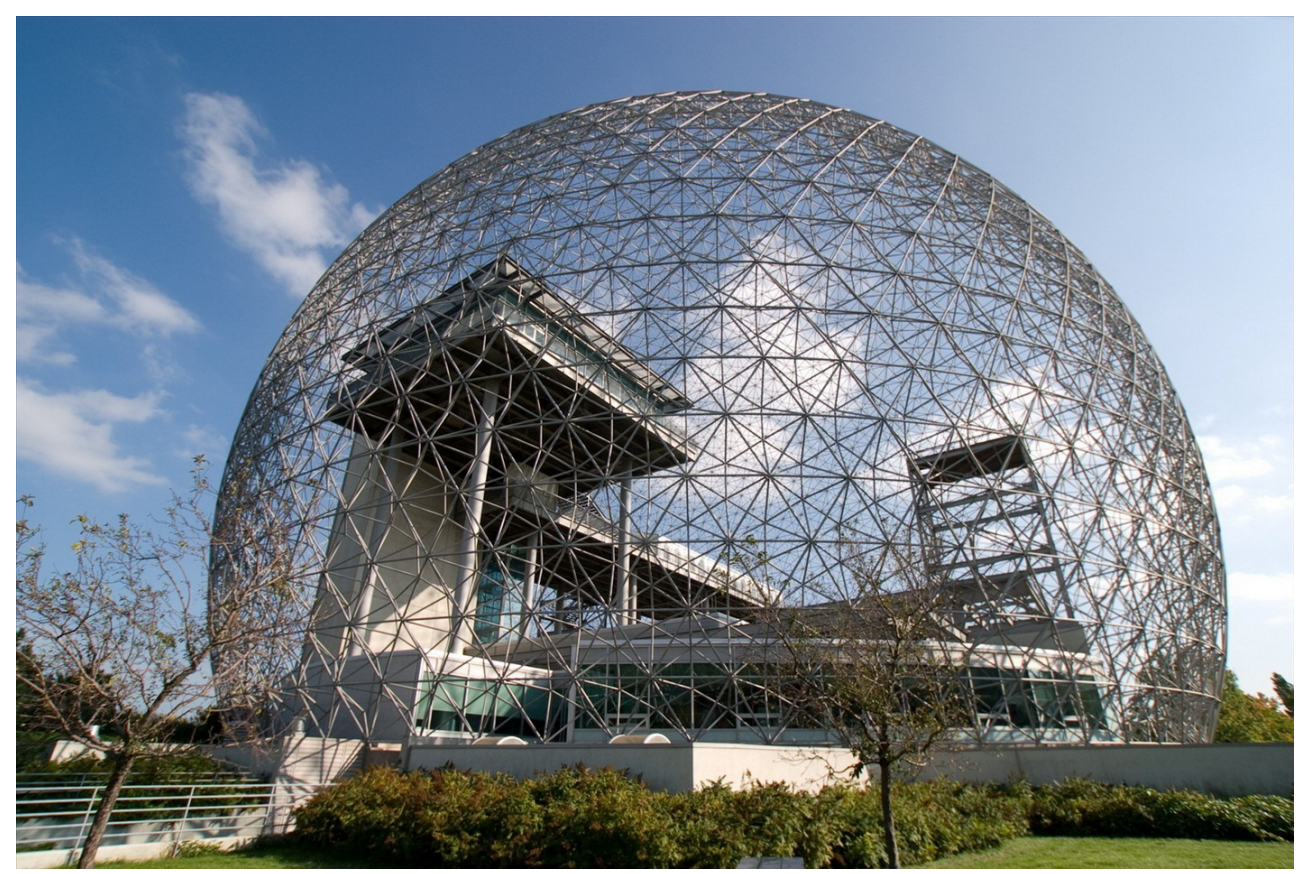

Fig. 4. Montreal, Biosphére, once the pavilion of the USA at the Expo 1967. (photo by Peter van den Hamer)

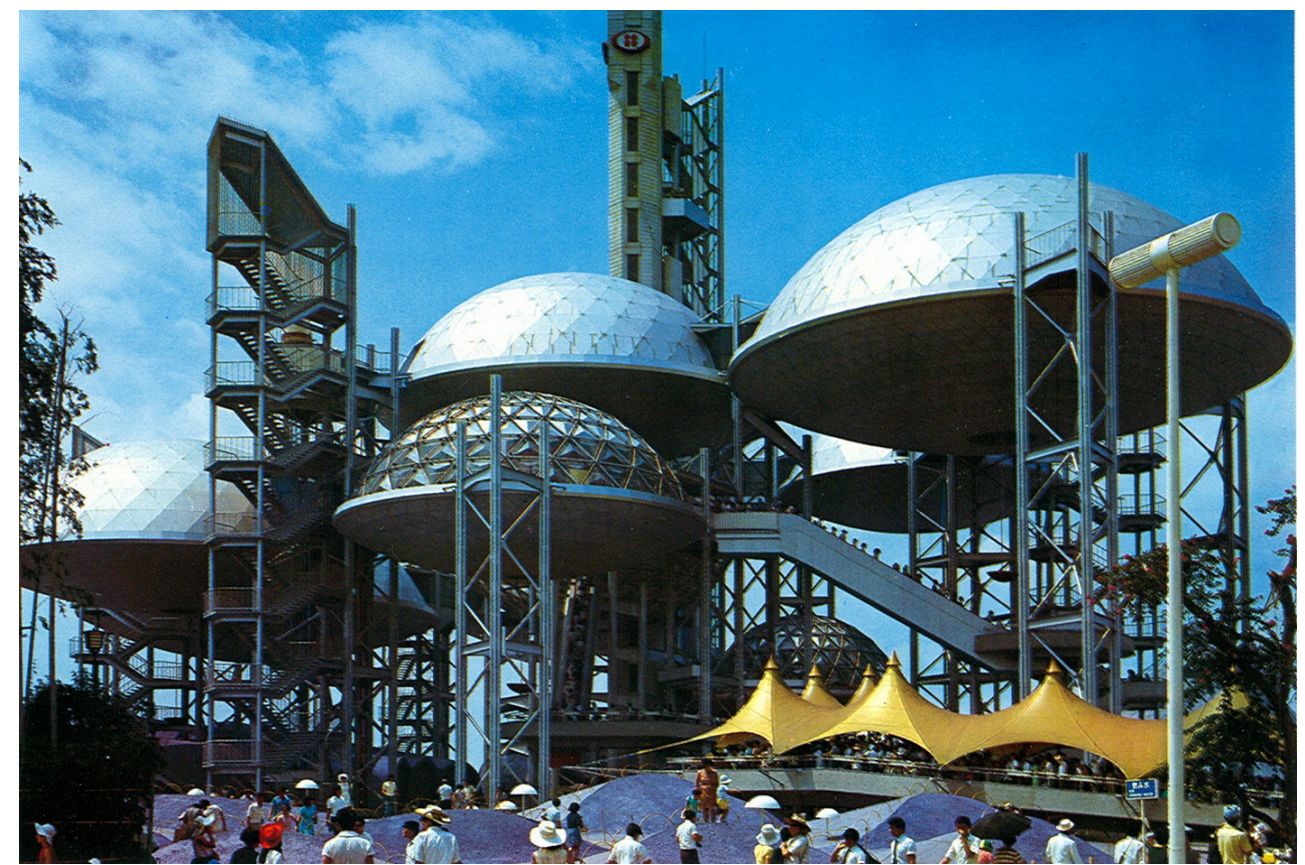

Fig. 5. Osaka, Sumitomo Tale pavilion, 1970. (source: ACEUJ, Exposition unvierselle du Japon, Osaka, 1970, rapport officielle, Osaka, 1972)

a transparent membrane skin for the 1967 Montreal Expo (German pavilion, with Rolf Gutbrod) and after the Munchen Olympic Arena in 1972 (with Jörg Schlaich) [11]. He was inspired by Shukhov (Rotunda at Nizhny Novgorod) and by Australian architect Barry Patten (Sidney Myer Music Bowl, 1959). After his pioneering work, tensile structures became widely used for large exhibition spaces (The Millennium Dome, London, Richard Rogers and Buro Happold, 2000), sports halls (Georgia Dome, Heery Int., 1992), and even airports (Denver International Airport, Fentress Architects, 1994). Frei Otto also experimented with convertible tent roofs for concert and sport facilities (open-air theatre of the abbey ruins of Bad Hersfeld, Germany 1968), and with pneumatic structures. The biggest pneumatic structures built were at the 1970 Osaka World Exposition. The U.S. Pavilion (Fig. 6) by architects Davis,

Brody, Chermayeff, Geismar and de Harak Associates covered a 80x142 meters super-elliptical structure with a translucent fiberglass fabric held up only by the internal air pressure [16]. Also the Mitsui, the Electric energy and the Fuji pavilions had pneumatic structures; this last one designed by architect Yutaka Murata and engineer Kawaguchi, was made of 16 arches of inflated plastic tubes, each $4 \mathrm{~m}$ in diameter and $72 \mathrm{~m}$ in length, arranged together in a circular plan, and formed a giant interior screening space [18]. This became the biggest air-inflated structure in the world. (Fig. 8) 


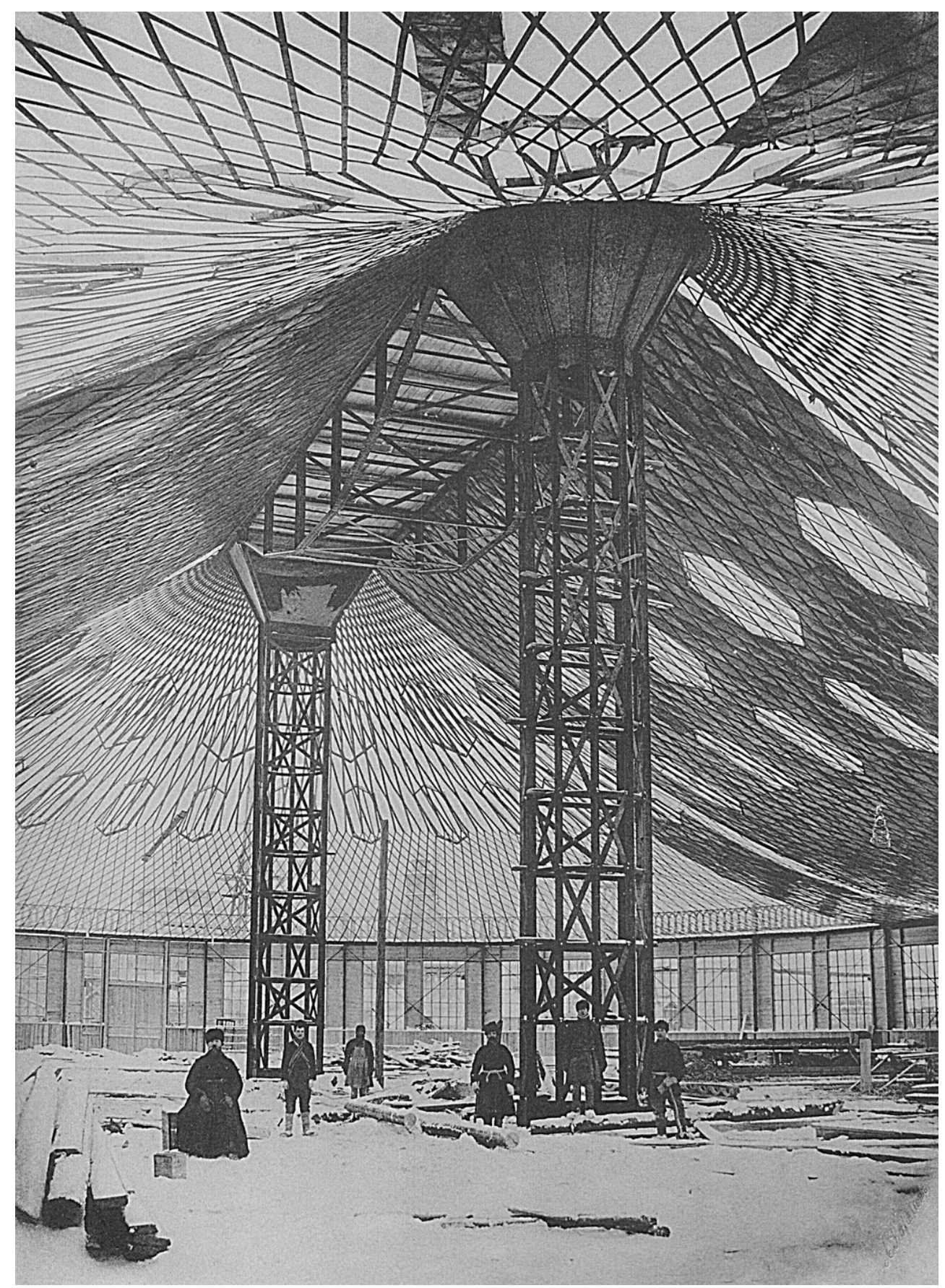

Fig. 6. Nizhny Novgorod, construction of the steel membrane roof for the All-Russia Industrial and Art Exhibition, 1896. (source: contemporary pho- tograph in: Giovannardi, F. Vladimir G. Shukhov e la leggerezza dell'acciaio. 2007.)

\section{A new tool for new structures: finite element method, CAD modelling and computer aided production}

The newest achievements in building structures and technology are related to the introduction and dissemination of computers in the engineering professions. The ability to calculate and model complex structures and later to guide the production of a singularly formed structural element had changed the aspect of building technology by the turn of the new millennium. The computing power available today makes possible the analysis of the structural behaviour of different materials in situations that were almost impossible to calculate with traditional mathematical formulas.
The finite element method (FEM) developed in the 50's, was first described as a usable method for resolving structural problems by Olgierd Zienkiewicz in 1947 [17]. With FEM a complex physical system can be divided into a finite number of discrete elements, easy to analyse and calculate, however only the calculation power of computers can handle the large number of these elements needed to make this approximation precise enough. With FEM, the structural analysis of tensile structures or membrane structures is easier, while the strength analysis of materials like glass or plastics, that did not have good models of calculations previously, also became possible.

One consequence of this new technological paradigm is the 


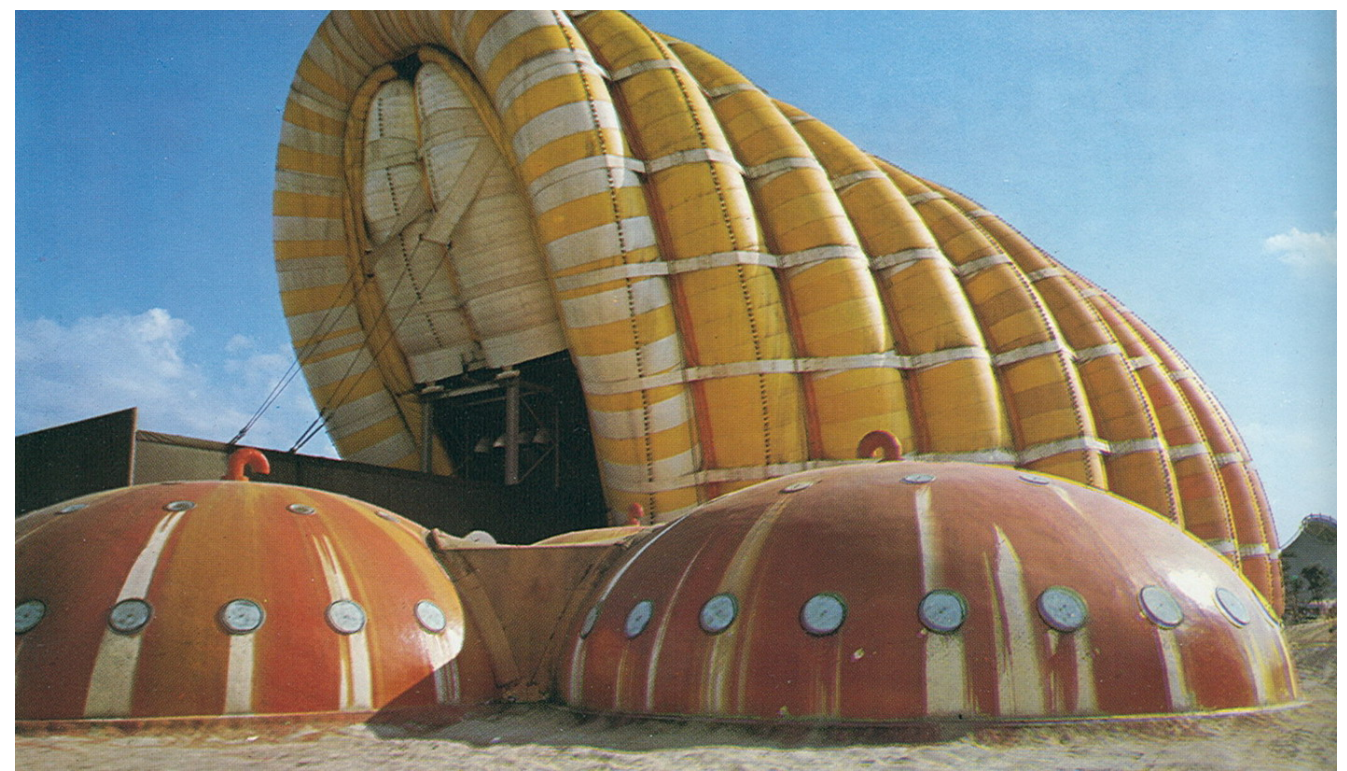

Fig. 7. Osaka, Fuji Group pavilion, 1970. (source: ACEUJ, Exposition unvierselle du Japon, Osaka, 1970, rapport officielle, Osaka, 1972)

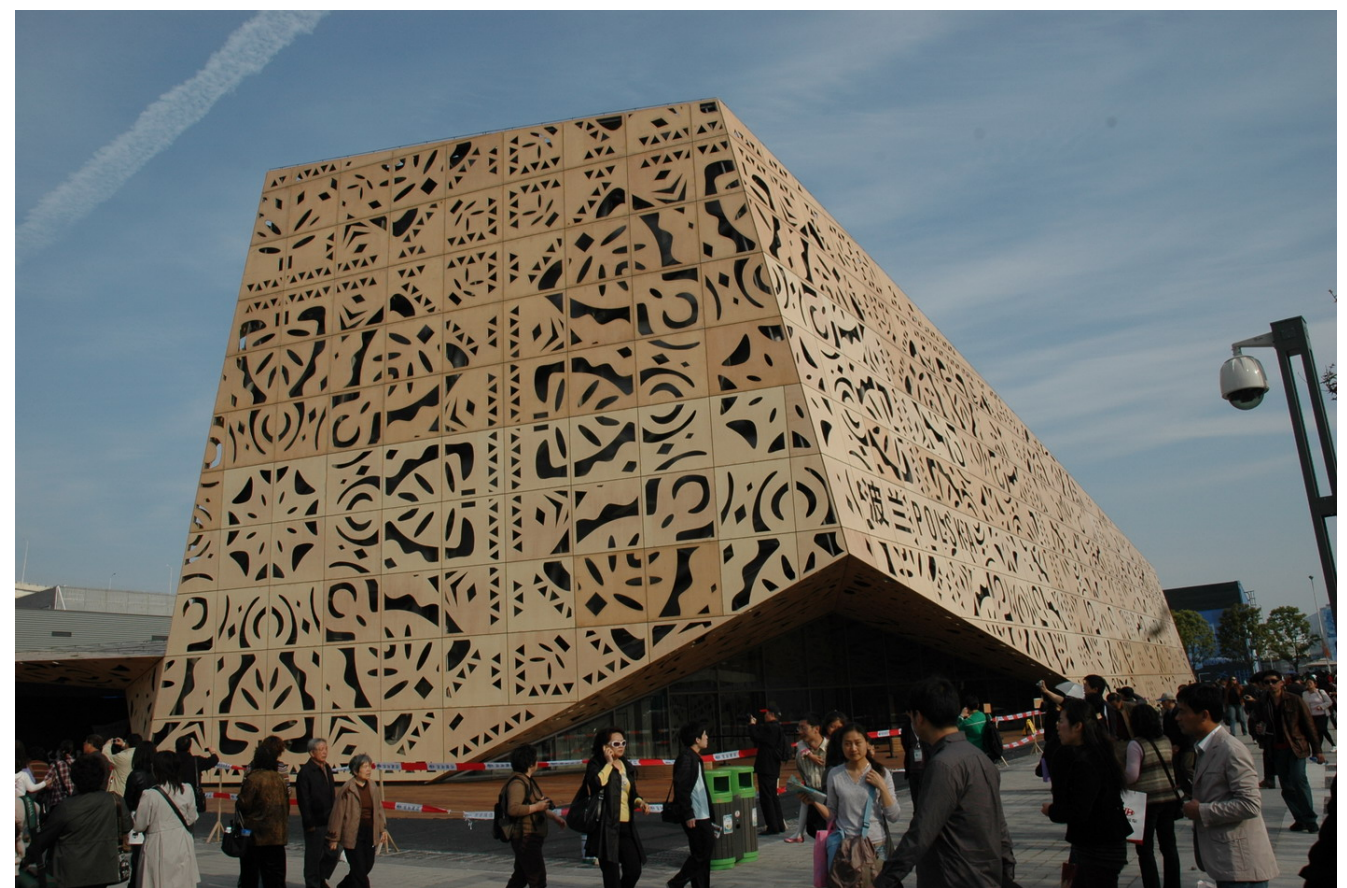

Fig. 8. Shanghai, Polish pavilion, 2010. (photo by Tamás Lévai and Ágnes Jószai)

application of glass as a building structure [3]. The use of glass as structural element results in transparent building parts, like roofs and walls, where no structural element blocks any part of the view.

One example for the usage of glass walls where the glass acts partly as a structural element is the German pavilion at the 2000 expo of Hanover by architect Josef Wund.

The finite element method made possible the calculation and modelling of special materials, but also of spatial structures. With FEM based CAD modelling software, non-standard architectural forms became easily calculable. As a result, the diffusion of this software in the architectural and engineering field led to the liberation of the basically tectonic form architects always used, and World expositions were still a good forum to introduce these new principles.

In Hanover MVRDV surprised the audience with the Dutch pavilion, a "landscape machine" consisting of five levels that are totally independent from each other in form and - at first sight - in structure. The structural engineers were ABT, the same as for the Happy Street - Dutch pavilion at World Expo 2010 (architect: John Körmeling), an extreme composition of hanging pavilions supported only by columns. Other aspects of the non-tectonic architecture are blobs and fluid forms. The computer-generated forms spreading in product design are nowadays present in architecture as well. A good example is the Austrian pavilion at Expo Shanghai 2010 by architects SPAN and Zeytinoglu, a fluid form covered by millions of hexagonal ceramics tiles [9]. 
With CAD and FEM systems, any form can be resolved structurally, and optimising is easy.

Modular systems are still favourable for their fast and recyclable construction methods, but CNC (Computer Numerical Control, production machines with a programmable computer controlling the output) and CAD (Computer Aided Design) bought cheap and fast originality. One important trend in architecture that grew out of CAD and has been realised only because of evolving CNC technology, is parametric design. A multitude of interconnected elements, which differ from each other according to given parameters, can form roofs and facades. Currently only a few built structures are made of these parametric forms, mainly small exhibition stands. These will grow to form great structures probably in the next World Exhibitions. However, CNC technology has already made its mark on many national pavilions in 2010. Both the Russian (P.A.P. ER architectural team) and the Polish pavilions (Fig. 8. Architects Wojciech Kakowski, Natalia Paszkowska and Marcin Mostafa) had facades with ornamental forms CNC-cut from cement sheets and plywood respectively.

These examples all outline the importance of the facade in contemporary expos, in fact, many of the building innovations can be observed in this field. The 2000 Expo of Hannover presented many new methods for building's coverings, like the Iceland pavilion's membrane structure with water flowing on it, or the layers of the Dutch pavilion by MVRDV [15]. The last Expo in Shanghai showed no turning from this tendency. The British pavilion (Seed Cathedral) designed by Heatherwick Studio is covered entirely by fibre glass cilia, transmitting light from the outside to the interior, while the whole building can smoothly wave in the wind. Similar in its extraordinary facade is the Swiss pavilion by Buchner Bründler (a light metal mesh with red bulbs hanging from it covers the building,) or the Spanish pavilion by EMBT (golden metallic mesh woven in a rustic way) [9].

\section{Green design}

After the optimistic themes of the Expos of the mid-20 $20^{\text {th }}$ century, more conscious approaches to development gained ground as the negative social and environmental aspects of growth began to worry society. In 1985 the Tsukuba exposition in Japan opened with the theme "People, Living, Environment and Science Technology", focusing more on sustainability, while the Hanover Expo of 2000 had "People-Nature-Technology: Demonstrating a Brand New World" as its theme, and promoted green thinking even with the planning and architecture of its site. The Hanover show took place in the traditional expo area of the city, $70 \%$ of the old buildings were kept and refurbished for the event. Some of the new structures were built to be recyclable afterwards, like the Spanish pavilion by A. Cruz Villalón and A. Ortiz Garcia which was a pyramid covered with cork, designed to be reused at different construction sites after the end of the expo (sadly this did not happen). Natural ventilation, low carbon emissions, solar systems were must-use technologies at the
Shanghai Expo, themed “Better City, Better Life”. The Chinese pavilion (designed by He Jingtang) reversed pyramid shape acts as a giant sun shade, but also incorporates solar technologies, collects rain water and uses natural ventilation. The same is true for the megastructure of the main axis, designed by Knippers Helbig Advanced Engineering 5 , and the Expo Center (Wang Xiao). The organizers claim that the Expo of Shanghai only used 9/10 of the energy used by previous expos.

Some exhibitor pavilions reflected green thinking not only in the technology they used, but also in the symbolism of their architecture, like the bamboo-wall of the Rhone-Alps region, the undulating facade made out of "rattan baskets" of the Spanish pavilion (Fig. 9] [10].

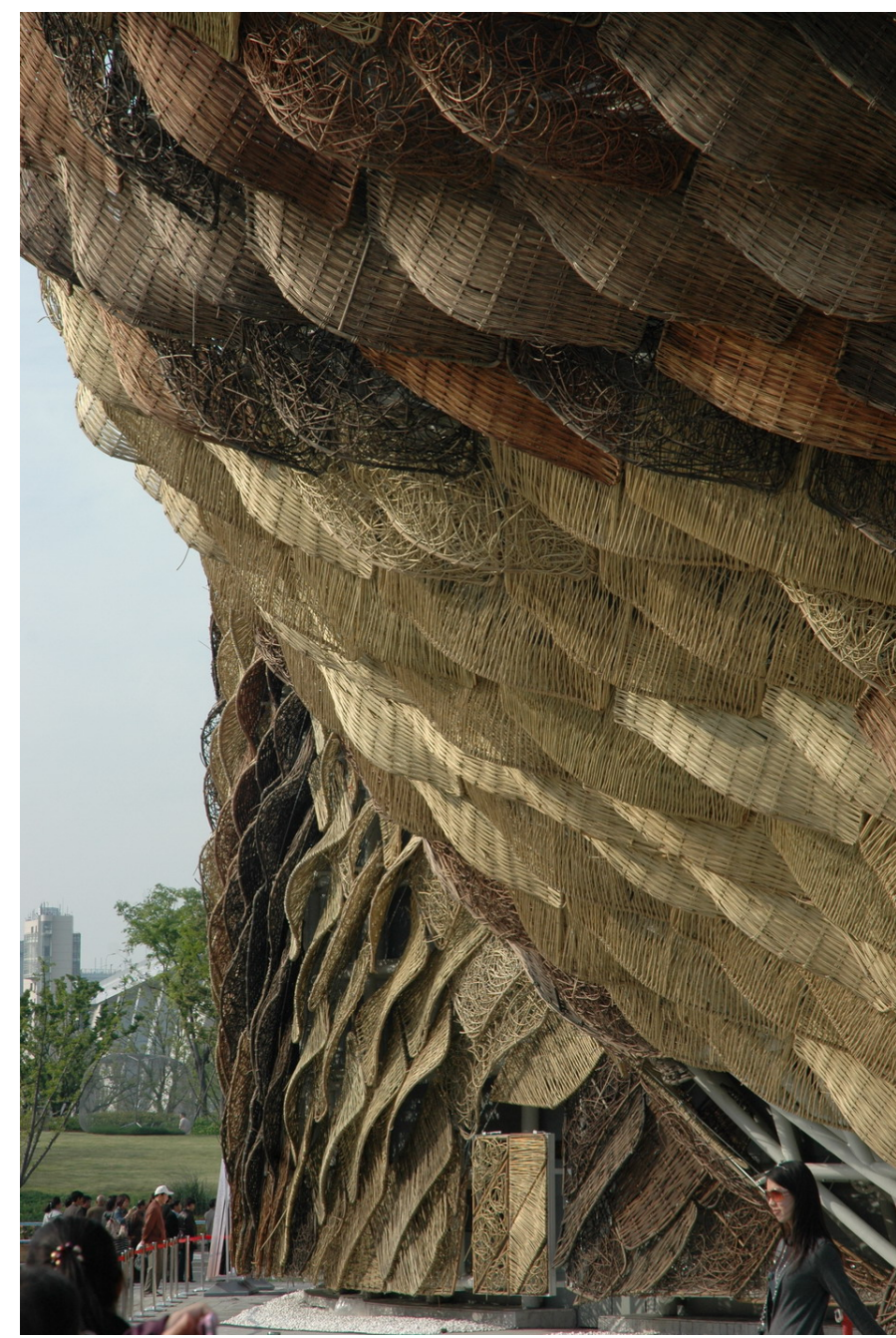

Fig. 9. Shanghai, Spanish pavilion, 2010. (photo by Tamás Lévai and Ágnes Jószai)

\section{Conclusion: the end of the primacy of structures}

Exposition halls and pavilions are great laboratories for new building techniques, but it seems that the optimistic race for bigger structures has come to an end. After the first golden age of World Expositions, the second half of the $19^{\text {th }}$ century, when host countries competed for the largest span and highest

\footnotetext{
${ }^{5}$ http://www.khing.de/
} 
structure, another peak in architectural and structural innovation came in the late 60's.

At the time, many utopias were considered using even bigger structural systems to build entire cities. Archigram envisioned prefabricated cities and moving structures ${ }^{6}$ Kenzo Tange and Japanese metabolists designed floating cities 7 and the great World Expositions of 1967 in Montreal and 1970 in Osaka were great laboratories for these ideas, full of experimental architecture and structural primacy. However, after the optimistic show of Osaka the world has changed. With the 1972 publication of "The Limits to Growth", a report of the Club of Rome [13] and the 1973 oil crisis, the optimistic race for a more technological environment and for bigger structures made no sense anymore.

Since then sustainability, social cohesion, media technologies and networking are the main topics present in Expos. These messages are carried by the pavilion's formal, tactile and visual quality, but not its size or structures. In the $21^{s t}$ century, building innovation focused more on carbon neutral solutions, interactive spaces or the skins of buildings. National competition is no longer about greatness and size, and on many occasions, it is not even a competition, as the rivalry is replaced by collaboration.

Great structural engineers still work on expo sites, but their biggest works are not necessarily these. Werner Sobek 8 designed structures for the Hamburg expo, the Shanghai-Pudong expo and the München expo, but he is famous for great structures in stadiums, train stations and museums, or recently the canteen of Trumf, and the solar design of "Cité du design" in a former weapons factory in St. Etienne. Cecil Balmond 9 was the structural engineer for the Portuguese pavilions of the Lisbon expo of 1998 (architecture: Alvaro Siza) and the Hannover expo of 2000 (architecture: Alvaro Siza and Eduardo Souto De Moura). However, his main works are related to great cultural and commercial buildings built in collaboration with celebrated architects, such as Rem Koolhaas (CCTV headquarters in Bejing), Sigheru Ban (Centre Pompidou in Metz) or Anish Kapoor (the ArcelorMittal Orbit in the Olympic park, London 2012). Arun ${ }^{10}$ worked with BIG on the awarded Danish pavilion of Shanghai expo 2010, and the Singapore and Korea pavilions, however their bigger works include the National Stadium and the "Water cube" of the Bejing Olympics of 2008, and the 600 meters tall Canton tower (inspired by the towers of Shukhov). These examples demonstrate how great structural quests in architecture are no longer tied to World Exhibitions. Structural ingenuity in commercial architecture and infrastructural or cultural projects often outstrips the greatest pavilions and exhibition halls of expos, nevertheless, as they were for 150 years, World Exhibitions are still the greatest laboratories for architec-

\footnotetext{
${ }^{6}$ Plug-in City (by Peter Cook, 1964) and Walking City (by Ron Herron, 1964)

${ }^{7}$ Floating City on Lake Kasumigaura (by Noriaki Kurokawa) or plan for Tokyo bay (by Kenzo Tange, 1960)

${ }^{8} \mathrm{http}: / /$ www.wernersobek.com/

${ }^{9}$ http://balmondstudio.com/

${ }^{10}$ http://www.arup.com/
}

tural innovation, even if nowadays, technology develops more around ecological and formal questions, rather than that of structure.

\section{References}

1 Geppert A T C, Coffey J, Lau T, Wolkenkuckucksheim: Internationale Zeitschrift für Theorie und Wissenschaft der Architektur, 2000. International Exhibitions, Expositions Universelles and World's Fairs, 1851-1951: A Bibliography Special Issue.

2 Billington D P, The tower and the bridge: the new art of structural engineering, Princeton University Press, 1985.

3 Bölcskey E, Transzparens teherhordó szerkezetek: a 21. század üvegépítészete, Epítés-Építészettudomány XXX (3-4), Akadémiai Kiadó, Budapest, pp. 207-228.

4 Chilton J C, Space grid structures, Elsevier, 2000.

5 Fuller R B, Krausse J, Lichtenstein C, Your private sky: R. Buckminster Fuller, the art of design science, Springer, 1999.

6 Giedion S, Space, time and architecture: The growth of a new tradition, Harvard University Press, 1997.

7 Giovannardi F, Vladimir G. Shukhov e la leggerezza dell'acciaio, 2007, available at http://www.giovannardierontini.it/Pubblicazioni/ Shukhov.pdf extracted on 2010.11.04.

8 Hobhouse $\mathbf{H}$, The Crystal Palace and the Great Exhibition: art, science, and productive ..., Continuum International Publishing Group, 2004.

9 Hornsby A, The branding of nations: using buildings to bid for Chinese cash, The Architectural Review 1261 (2010), 108.

10 Jiaqing G, Yiqun $\mathbf{H}$, The Application and Research of Green Design in the Pavilions of Shanghai Expo, 2010 3rd International Conference on Information Management, Innovation Management and Industrial Engineering.

11 Kenneally R R, Expo 67: Not Just a Souvenir, University of Toronto Press, 2010.

12 Lin Z, Kenzo Tange and the Metabolist movement: urban utopias of modern Japan, Taylor \& Francis, 2010.

13 Meadows D H, The limits to growth : a report for club of Rome's project, Universe Books, 1972.

14 Parke G A R, Disney P, Space structures 5, Vol. 1, Thomas Telford, 2002.

15 Shchittich C (ed.), In Detail: Building Skins: Concepts, Layers, Materials, Birkhauser, 2001.

16 Villecco M, The infinitely expandable future of air structures, 1970. Architectural Forum.

17 Zienkiewicz O. C, Taylor R. L, The finite element method for solid and structural mechanics, Butterworth-Heinemann, 2005.

18 ACEUJ, Exposition unvierselle du Japon, Osaka, 1970. rapport officielle, Osaka, 1972. 